\title{
PENGARUH PENGAWASAN, LINGKUNGAN KERJA, FASILITAS KERJA TERHADAP PRESTASI KERJA PEGAWAI DINAS PANGAN DAN PERTANIAN KOTA TANJUNGBALAI
}

\author{
${ }^{1}$ Azhari, ${ }^{2}$ Widyaseno Trusyuwono, ${ }^{3}$ Rahwati, ${ }^{4}$ Ahmad Zen, ${ }^{5}$ Siti Aminah Nasution. \\ ${ }_{1,2,3,4,5}$ Universitas Islam Sumatera Utara \\ Iazhari.mm@gmail.com, ${ }^{2}$ widyaseno.trusy@gmail.com,3rahwati.mm@gmail.com, ${ }^{4}$ ahmad.zen@gmail.com, \\ ${ }^{5}$ siti.aminahnst@gmail.com
}

\begin{abstract}
The formulation of the problem in this research is: How do the effects of supervision, work environment, work facilities on the work performance at Dinas Pangan Dan Pertanian Kota Tanjungbalai. This study aims to determine the effect of supervision, work environment, work facilities on employee performance. With a non probability sampling technique, the sample in this study was 38 people. The results showed; Partial supervision has a positive effect on employee work performance of 3,937; The work environment partially has a positive effect on employee work performance by 2,942; Work facilities partially have a positive effect on employee work performance of 3.507; Supervision, work environment and work facilities simultaneously have a positive and significant effect on employee work performance of 31.188 .
\end{abstract}

Keywords : Supervision; Work environment; Work Facilities; Work performance.

ABSTRAK : Rumusan masalah dalam penelitian ini adalah : Bagaimana pengaruh pengawasan, lingkungan kerja, fasilitas kerja terhadap prestasi kerja pegawai Dinas Pangan Dan Pertanian Kota Tanjungbalai. Penelitian ini bertujuan untuk mengetahui pengaruh pengawasan, lingkungan kerja, fasilitas kerja terhadap prestasi kerja pegawai. Dengan teknik non probability sampling maka sampel dalam penelitian ini sebanyak 38 orang. Hasil penelitian menunjukkan; Pengawasan secara parsial berpengaruh positif terhadap prestasi kerja pegawai sebesar 3,937; Lingkungan kerja secara parsial berpengaruh positif terhadap prestasi kerja pegawai sebesar 2,942; Fasilitas kerja secara parsial berpengaruh positif terhadap prestasi kerja pegawai sebesar 3,507; Pengawasan, lingkungan kerja dan fasilitas kerja secara simultan memiliki pengaruh yang positif dan signifikan terhadap prestasi kerja pegawai sebesar 31,188.

Kata Kunci : Pengawasan; Lingkungan Kerja; Fasilitas Kerja; Prestasi Kerja

\section{Pendahuluan}

Berdasarkan Undang-Undang Nomor 46 Tahun 2011 mengenai Pokok- Pokok Kepegawaian, setiap pegawai negeri sipil (PNS) dituntut untuk dapat memberikan pelayanan dengan sebaik-baiknya kepada masyarakat. Untuk menyelenggarakan tugas pemerintahan dan pembangunan ekonomi dengan baik maka dibutuhkan pegawai negeri sipil yang profesional, jujur, adil dan bertanggung jawab.

Prestasi kerja pegawai merupakan hal yang sangat penting dalam instansi untuk mencapai tujuannya, sehingga instansi melakukan berbagai usaha untuk meningkatkannya. Prestasi dalam bekerja merupakan salah satu kebutuhan yang ingin dicapai setiap orang dalam bekerja. Prestasi kerja pegawai tidak sama hasilnya dengan rencana yang di tetapkan, hal ini disebabkan karena setiap pegawai mempunyai kemampuan dan kemauan yang berbeda untuk melaksanakan pekerjaan.

Dapat dilihat pada data laporan kinerja bulanan pegawai Dinas Pangan Dan Pertanian Kota Tanjungbalai selama empat bulan terakhir sebagai berikut: 
Tabel 1. Laporan Prestasi Kerja Bulanan Pegawai Dinas Pangan Dan Pertanian Kota Tanjungbalai Tahun 2020

\begin{tabular}{|l|r|r|r|r|r|r|r|r|r|r|r|r|}
\hline \multirow{2}{*}{ KETERANGAN } & \multicolumn{4}{|c|}{ JULI } & \multicolumn{3}{|c|}{ AGUSTUS } & \multicolumn{3}{|c|}{ SEPTEMBER } & \multicolumn{3}{|c|}{ OKTOBER } \\
\cline { 2 - 15 } & B & S & $\begin{array}{c}\text { Nilai } \\
(\%)\end{array}$ & B & S & $\begin{array}{c}\text { Nilai } \\
(\%)\end{array}$ & B & S & $\begin{array}{c}\text { Nilai } \\
(\%)\end{array}$ & B & S & $\begin{array}{c}\text { Nilai } \\
(\%)\end{array}$ \\
\hline Target Kerja Pegawai & 60 & 84,5 & 50,7 & 60 & 85,5 & 513 & 60 & 83,2 & 49,9 & 60 & 81,5 & 48,9 \\
\hline Prilaku & 40 & 87 & 34,8 & 40 & 89,5 & 35,8 & 40 & 75,4 & 30,2 & 40 & 74,3 & 29,7 \\
\hline Jumlah & 100 & & 85,5 & 100 & & 87,1 & 100 & & 80,1 & 100 & & 78,6 \\
\hline
\end{tabular}

Keterangan: $\mathrm{B}=$ Bobot, $\mathrm{N}=$ Nilai, $\mathrm{S}=$ Skor

Berdasarkan Tabel 1.1 diketahui bahwa prestasi pegawai di Dinas Pangan Dan Pertanian Kota Tanjungbalai yaitu $85,5 \%$ di bulan Juli tahun 2020 sedangkan pada bulan Agustus tahun 2020 meningkat menjadi $87,1 \%$ kemudian mengalami penurunan pada bulan September tahun 2020 menjadi $80,1 \%$ kemudian mengalami penurunan kembali pada bulan Oktober tahun 2020 menjadi $78,6 \%$. Hal ini menunjukkan bahwa semakin menurunnya presentase prestasi kerja pegawai, yang bertentangan dengan salah satu tugas pokok dan fungsinya yaitu peningkatan kapasitas SDM aparatur.

Berdasarkan hasil wawancara dengan salah satu pegawai bidang kepegawaian terdapat permasalahan mengenai prestasi kerja yaitu, pegawai tidak mampu mengerjakan tugas secara rapih, pegawai tidak mampu mengerjakan tugas secara tuntas, pegawai tidak sesuai dengan standar yang ditetapkan, pegawai kurang memiliki rasa tanggung jawab terhadap tugasnya. Tentunya hal tersebut jauh dari harapan organisasi yang menginginkan para pegawainya memiliki prestasi kerja yang baik.

Banyak faktor yang mempengaruhi dalam diri maupun yang berasal dari lingkungan organisasi tempat pegawai bekerja, diantaranya rekrutmen, seleksi, pengawasan, penempatan, pendidikan dan pelatihan, kemampuan, stres kerja, fasilitas kerja, disiplin, lingkungan kerja, motivasi, kompensasi, budaya organisasi, kepemimpinan, pengembangan karir pegawai Kopelman (2011: 139). Faktor-faktor tersebut hendaknya diperhatikan oleh pimpinan instansi sehingga prestasi kerja pegawai dapat optimal. Kopelman (2011: 154) menambahkan bahwa prestasi kerja pegawai selain dipengaruhi oleh faktor lingkungan juga sangat tergantung dari karakteristik individu seperti kemampuan, pengetahuan, keterampilan, motivasi, norma dan nilai. Untuk mengetahui apa faktor penyebab menurunnya prestasi kerja pegawai, maka peneliti melakukan penelitian pendahuluan. Penelitian dilakukan kepada 15 orang pegawai yang ada di Dinas Pangan Dan Pertanian Kota Tanjungbalai secara acak. Kuesioner bertanya tentang tingkat kepentingan variabel-variabel yang dapat mempengaruhi prestasi kerja pegawai berdasarkan penadapat ( Kopelman, 2011:139-154), hasil nya dapat di lihat pada tabel 1.2 berikut; prestasi kerja pegawai baik yang berasal dari

Tabel 2. Studi Pendahuluan Kuesioner Variabel-variabel yang Berpengaruh Terhadap Prestasi Kerja Pegawai Dinas Pangan Dan Pertanian Kota Tanjungbalai

\begin{tabular}{|r|r|r|r|r|}
\hline No & Variabel & \multicolumn{1}{|c|}{ S } & \multicolumn{1}{c|}{ TS } & Jumlah \\
\hline 1 & Lingkungan Kerja & 13 & 2 & \\
\hline 2 & Motivasi & 10 & 5 & \\
\hline 3 & Disiplin & 9 & 6 & \multirow{2}{*}{15} \\
\hline 4 & Kepemimpinan & 7 & 8 & \\
\hline 5 & Budaya Organisasi & 5 & 10 & \\
\hline 6 & Pengawasan & 14 & 1 & \\
\hline 7 & Stres Kerja & 6 & 9 \\
\hline 8 & Kompensasi & 6 & 9 & \\
\hline 9 & Fasilitas kerja & 12 & 3 \\
\cline { 1 - 2 } 10 & Keterampilan & 9 & 6 \\
\hline 11 & Norma dan Nilai & 10 & 5 & \\
Sumber: Hasil olah data kuesioner pra survey (2020)
\end{tabular}


Berdasarkan pada tabel 1.2 yang ada di atas, menunjukkan bahwa hasil studi pendahuluan kuesioner mengenai variabelvariabel yang paling berpengaruh terhadap prestasi kerja pegawai Dinas Pangan Dan Pertanian Kota Tanjungbalai yakni ;

Pada variabel pengawasan, terdapat 14 responden yang memilih setuju dengan pernyataan bahwa adanya pengaruh prestasi kerja pegawai yang disebabkan oleh kurangnya pengawasan yang merupakan cara dalam pembinaan pegawai dalam menggerakan pegawai dalam pencapaian prestasi kerja yang baik.. Dengan harapan hasil dari pengawasan yang lebih interen yang di selenggarakan dapat membantu pegawai dalam meningkatkan prestasi kerjanya guna mencapai target dan harapan instansi.

Pada variabel lingkungan kerja, terdapat 13 responden yang memilih setuju dengan pernyataan bahwa adanya pengaruh prestasi kerja pegawai yang disebabkan oleh kondisi lingkungan kerja pegawai separti halnya keadaan kantor yang kurang kondusif. Pegawai masih sering terlihat merasa tidak nyaman dengan keadaan lingkungan yang bising, ruangan yang tidak rapi, arome yang tidak sedap dan lain - lain hal ini menyebabkan pegawai merasa kurang nyaman dan terganggu dan akan mengurangi prestasi kerja pegawai itu sendiri.

Pada variabel fasilitas kerja, terdapat 12 responden yang memilih setuju dengan pernyataan bahwa adanya pengaruh prestasi kerja pegawai yang disebabkan oleh kurangnya ketersediaan fasilitas kerja. Karena dengan tersedainya fasilitas kerja yang baik dapat membantu meningkatkan prestasi kerja pegawai yang pada akhirnya akan meningkatkan gairah pegawai dalam bekerja. Sebaliknya apabila fasilitas yang tersedia kepada pegawai kurang baik dalam ketersediannya bagaimana mereka mampu memenuhi target dalam bekerja, sehingga pegawai merasa dalam bekerja sangat terbebani dan ini jelas akan berdampak pada prestasi kerja mereka.

Peranan prestasi kerja pegawai dalam instansi sangatlah penting. Prestasi kerja pegawai yang baik dapat memperlancar penggerak utama seluruh kegiatan instansi dalam mencapai tujuan instansi, yaitu untuk mempertahankan kelangsungan hidup instansi maupun untuk memperoleh keuntungan. Berhasil tidaknya suatu instansi dalam mempertahankan eksistensinya dimulai dari usaha manusia itu sendiri dalam melaksanakan pekerjaannya secara maksimal. Kinerja perusahaan sangat dipengaruhi bahkan sangat tergantung pada kualitas sumber daya manusia yang dimilikinya termasuk prestasi kerja para pegawainya. Baharudin et al, (2013 : 172) menyatakan prestasi kerja pegawai sangat menentukan kemajuan dan kualitas instansi.

\subsection{Rumusan Masalah}

Berdasarkan latar belakang masalah tersebut diatas, maka yang menjadi rumusan masalah dalam penelitian ini adalah :

a. Bagaimana pengaruh pengawasan terhadap prestasi kerja pegawai Dinas Pangan Dan Pertanian Kota Tanjungbalai?

b. Bagaimana pengaruh lingkungan kerja terhadap prestasi kerja pegawai Dinas Pangan Dan Pertanian Kota Tanjungbalai?

c. Bagaimana pengaruh fasilitas kerja terhadap prestasi kerja pegawai Dinas Pangan Dan Pertanian Kota Tanjungbalai?

d. Bagaimana pengaruh pengawasan, lingkungan kerja, fasilitas kerja terhadap prestasi kerja pegawai Dinas Pangan Dan Pertanian Kota Tanjungbalai?

\subsection{Batasan Masalah}

Penelitian ini di batasi hanya pada pengawasan, lingkungan kerja, fasilitas kerja terhadap prestasi kerja pegawai Dinas Pangan Dan Pertanian Kota Tanjungbalai.

\subsection{Hioptesis}

Berdasarkan perumusan masalah dan kerangka pemikiran diatas, maka hipotesis dalam penelitian ini adalah sebagai berikut :

a. Pengawasan berpengaruh postif dan signifikan terhadap prestasi kerja pegawai

b. Lingkungan kerja berpengaruh positif dan signifikan terhadap prestasi kerja pegawai

c. Fasilitas kerja berpengaruh poitif dan signifikan terhadap prestasi kerja pegawai

d. Pengawasan, lingkungan kerja, fasilitas kerja berpengaruh positif dan signifikan terhadap prestasi kerja pegawai.

\subsection{Tujuan Penelitian}

Berdasarkan rumusan masalah penelitian sebagaimana diuraikan di atas, maka tujuan yang hendak dicapai dalam penelitian ini yaitu: 
a. Untuk mengetahui pengaruh pengawasan terhadap prestasi kerja pegawai Dinas Pangan Dan Pertanian Kota Tanjungbalai

b. Untuk mengetahui pengaruh lingkungan kerja terhadap prestasi kerja pegawai Dinas Pangan Dan Pertanian Kota Tanjungbalai

c. Untuk mengetahui pengaruh fasilitas kerja terhadap prestasi kerja pegawai Dinas Pangan Dan Pertanian Kota Tanjungbalai

d. Untuk mengetahui pengaruh pengawasan, lingkungan kerja, fasilitas kerja terhadap prestasi kerja pegawai Dinas Pangan Dan Pertanian Kota Tanjungbalai

\section{Metode Penelitian}

\subsection{Populasi}

Populasi merupakan ruang lingkup yang menjadi sumber data penelitian sesuai dengan masalah yang diteliti. Menurut Hadjar (dalam Purwanto, 2012: 241) mengemukakan bahwa "populasi adalah kelompok besar individu yang mempunyai karakteristik umum yang sama". Sedangkan menurut (Sugiyono, 2013: 90) mengemukakan bahwa populasi adalah wilayah generalisasi yang terdiri atas subjek/objek yang mempunyai kualitas dan karakteristik tertentu yang ditetapkan oleh peneliti untuk dipelajari dan kemudian ditarik kesimpulannya.

Dalam penelitian ini yang menjadi populasi penelitian adalah pegawai Dinas Pangan dan Pertanian Kota Tanjungbalai dengan jumlah 40 orang.
Tabel 3. Kerangka Populasi Berdasarkan Jabatan Thn. 2020

\begin{tabular}{|r|l|r|}
\hline No & \multicolumn{1}{|c|}{ Jabatan } & \multicolumn{1}{|c|}{ Jlh } \\
\hline 1 & Kepala Dinas & 1 \\
\hline 2 & Sekretaris & 1 \\
\hline 3 & Kepala Bidang & 4 \\
\hline 4 & Kepala Seksi & 9 \\
\hline 5 & Kepala Sub Bagian & 3 \\
\hline 6 & Kepala UPTD & 4 \\
\hline 7 & Bendahara & 2 \\
\hline 8 & Seksi & 2 \\
\hline 9 & Pengadmin & 6 \\
\hline 10 & Pengelola & 5 \\
\hline 11 & Penyuluh & 3 \\
\hline Jumlah & $\mathbf{4 0}$ \\
\hline
\end{tabular}

Sumber: Dinas Pangan dan Pertanian Kota Tanjungbalai $-2020$

\subsection{Sampel}

Sampel adalah bagian atau wakil populasi yang diteliti. Sampel adalah bagian dari jumlah dan karakteristik yang dimiliki oleh populasi tersebut (Sugiyono, 2013:91). Dalam penelitian ini penulis menggunakan teknik sampling yaitu teknik non probability sampling. Menurut Sugiyono, (2013:95) teknik non probability sampling adalah teknik pengambilan sampel yang tidak memberi peluang atau kesempatan sama bagi setiap unsur atau anggota populasi untuk dipilih menjadi sampel. Dalam penelitian ini digunakan sampel dari seluruh populasi dengan jumlah 38 responden di karenakan Kepala Dinas dan Kepala Seksi sebagai peneliti tidak ikut dijadikan sampel dalam penelitian ini.

Tabel 4.Kerangka Distribusi Sampel Berdasarkan Jabatan Thn. 2020

\begin{tabular}{|r|l|c|c|c|}
\hline No & Jabatan & Jlh Populasi & Jlh Sampel & Keterangan \\
\hline 1 & Kepala Dinas & 1 & - & Tidak diteliti \\
\hline 2 & Sekretaris & 1 & 1 & Diteliti \\
\hline 3 & Kepala Bidang & 4 & 4 & Diteliti \\
\hline 4 & Kepala Seksi & 9 & 8 & 1 Orang Peneliti \\
\hline 5 & Kepala Sub Bagian & 3 & 3 & Diteliti \\
\hline 6 & Kepala UPTD & 4 & 4 & Diteliti \\
\hline 7 & Bendahara & 2 & 2 & Diteliti \\
\hline 8 & Seksi & 2 & 2 & Diteliti \\
\hline 9 & Pengadmin & 6 & 6 & Diteliti \\
\hline
\end{tabular}




\begin{tabular}{|c|l|c|c|c|}
\hline No & Jabatan & Jlh Populasi & Jlh Sampel & Keterangan \\
\hline 10 & Pengelola & 5 & 5 & Diteliti \\
\hline 11 & Penyuluh & 3 & 3 & Diteliti \\
\hline Jumlah & $\mathbf{4 0}$ & $\mathbf{3 8}$ & \\
\hline
\end{tabular}

Sumber: Dinas Pangan dan Pertanian Kota Tanjungbalai - 2020

\subsection{Uji Normalitas}

Pengujian normalitas data bertujuan untuk melihat normal tidaknya sebaran data yang akan dianalisis. Model regresi yang baik adalah distribusi normal atau mendekati normal. Untuk melihat normalitas data ini digunakan pendekatan grafik yaitu Normality Probability Plot.

Deteksi normalitas dengan melihat penyebaran data (titik) pada sumbu diagonal dari grafik. Menurut Santoso (2014:214), dasar pengambilan keputusan adalah:

a. Jika data menyebar disekitar garis diagonal dan mengikuti arah garis diagonal, maka model regresi memenuhi asumsi normalitas.

b. Jika data menyebar jauh dari garis diagonal dan atau tidak mengikuti arah garis diagonal, maka model regresi tidak memenuhi asumsi normalitas. Pada output SPSS versi 24.00 bagian normal $P-P$ Plot of Regresion

Standardized Residual, dapat dijelaskan bahwa data-data (titik-titik) cenderung lurus mengikuti garis diagonal sehingga data dalam penelitian ini cenderung berdistribusi normal, seperti terlihat pada gambar dibawah ini.

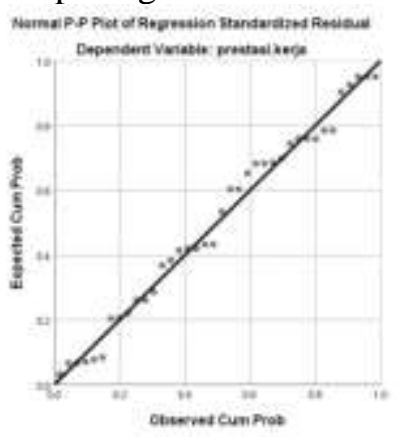

Gambar 1. Normalitas Data

\subsection{Uji Multikolinearitas}

Pengujian multikolinearitas dilakukan untuk melihat apakah pada model regresi ditemukan adanya korelasi antara variabel bebas. Jika terjadi korelasi, maka dinamakan terdapat problem multikolinearitas. Cara mendeteksinya adalah dengan melihat nilai Variance Inflation Factor (VIF). Menurut Santoso (2014:203), pada umumnya jika VIF lebih besar dari 5, maka variabel bebas tersebut mempunyai persoalan multikolinearitas dengan variabel bebas lainnya.

Pada ouput SPSS bagian Coefficient, semua angka VIF berada dibawah 5, hal ini menunjukan tidak terjadi multikolinearitas, seperti dapat dilihat pada tabel dibawah ini.

Tabel 5. Uji Multikolinearitas

\begin{tabular}{|c|c|c|c|}
\hline \multicolumn{4}{|c|}{ Coefficients $^{\mathrm{a}}$} \\
\hline \multirow{2}{*}{\multicolumn{2}{|c|}{ Model }} & \multicolumn{2}{|c|}{ Collinearity Statistics } \\
\hline & & Tolerance & VIF \\
\hline \multirow{4}{*}{1} & (Constant) & & \\
\hline & pengawasan & .734 & 1.362 \\
\hline & lingkungan.kerja & .795 & 1.258 \\
\hline & fasilitas.kerja & .639 & 1.566 \\
\hline
\end{tabular}

\subsection{Uji Heteroskedastisitas}

Pengujian heteroskedastisitas bertujuan untuk melihat apakah dalam sebuah model regresi terjadi ketidaksamaan varians dari residual yang merupakan suatu pengamatan ke pengamatan yang lainnya. Jika varians dari residual yang merupakan suatu pengamatan ke pengamatan yang lain bernilai tetap, maka hasil data disebut homoskedastisitas dan jika varians berbeda atau bernilai tidak tetap maka disebut heteroskedastisitas. Model regresi yang baik adalah model yang bernilai tetap atau homoskedastisitas atau tidak terjadi heteroskedastisitas.

Deteksi heteroskedastisitas dilakukan dengan cara melihat ada tidaknya pola tertentu pada data yang diolah. Menurut Santoso (2014:208), dasar pengambilan keputusannya adalah:

a. Jika pola tertentu seperti titik-titik yang ada membentuk suatu pola tertentu yang teratur, maka terdapat situasi heteroskedastisitas.

b. Jika tidak ada pola yang jelas, serta titiktitik menyebar diatas dan dibawah angka nol pada sumbu Y, maka tidak terjadi heteroskedastisitas. 
Pada output SPSS dibagian Scatrerplot, terlihat titk-titik menyebar secara acak, tidak membentuk sebuah pola tertentu yang jelas, serta tersebar baik diatas maupun dibawah angka nol pada sumbu Y. Hal ini berarti tidak terjadi heterskedastisitas pada model regresi, sehingga model regresi layak dipakai. Pola Scatterplot dapat dilihat pada gambar dibawah ini.

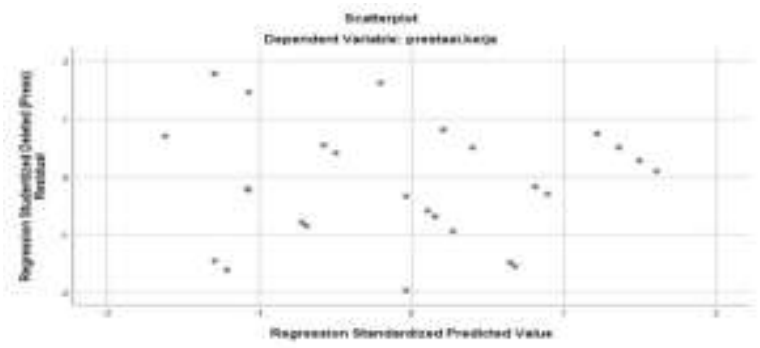

Gambar 2. Uji Heteroskedastitas

\section{Evaluasi Data (Analisa Regresi Linier Berganda ) \\ 3.1 Pengujian Hipotesis}

Dalam evaluasi data ini penulis akan melakukan pengujian hipotesis, baik secara partial ataupun secara simultan. Selanjutnya untuk mempermudah dalam evaluasi data ini, maka penulis mencari niali-nilai yang dibutuhkan dengan menggunakan perangkat lunak komputer yaitu program SPSS V.24.00 for windows dengan hasil data sebagai berikut:

Tabel 6. Hasil Uji Statistik Keofesien Regresi

\begin{tabular}{|c|c|c|c|c|c|c|}
\hline & & & oefficients ${ }^{\mathbf{a}}$ & & & \\
\hline & del & Unstal & dardized & Standardized & $\mathrm{t}$ & Sig. \\
\hline & & Coef & $\begin{array}{l}\text { ficients } \\
\text { Std Frror }\end{array}$ & Coefficients & & \\
\hline & (Constant) & 3.790 & 4.454 & & .851 & .401 \\
\hline 1 & pengawasan & .374 & .095 & 407 & 3.937 & .000 \\
\hline & lingkungan.kerja & .257 & .087 & .292 & 2.942 & .006 \\
\hline & fasilitas.kerja & .341 & .097 & .389 & 3.507 & .001 \\
\hline
\end{tabular}

Berdasarkan tabel 6 diatas dapat dibuat persamaan regresi sebagai berikut: $\mathrm{Y}=\mathrm{a}+$ $\mathrm{b} 1 \mathrm{X} 1+\mathrm{b} 2 \mathrm{X} 2+\mathrm{b} 3 \mathrm{X} 3+\varepsilon$

$Y=3,790+0,374 X_{1}+0,257 X_{2}+0,341 X_{3}+$

$\varepsilon$

Persamaan diatas dijelaskan bahwa koefesien pengawasan bernilai positif yaitu 0,374 , dengan demikian bahwa variabel pengawasan memiliki pengaruh yang positif terhadap prestasi kerja.

Berdasarkan persamaan diatas bahwa koefesien lingkungan kerja bernilai positif yaitu 0,257. Dengan demikian bahwa variabel lingkungan kerja mempunyai pengaruh positif terhadap prestasi kerja.

Berdasarkan persamaan diatas bahwa koefesien fasilitas kerja bernilai positif yaitu 0,341 . Dengan demikian bahwa variabel fasilitas kerja juga mempunyai pengaruh positif terhadap prestasi kerja.

\subsection{Pengujian Secara Simultan (Uji F)}

Untuk melihat hasil seberapa besar pengaruh yang di berikan variabel independen terhadap dependen secara simultan ( bersamasama ) pada penelitian ini maka dapat di jelaskan pada tabel di bawah ini :

Tabel 7. Hasil Uji Statistik Secara Simultan

\begin{tabular}{|c|c|c|c|c|c|c|}
\hline \multicolumn{2}{|c|}{ Model } & \multirow{2}{*}{$\begin{array}{r}\begin{array}{l}\text { Sum of } \\
\text { Squares }\end{array} \\
40.611\end{array}$} & \multirow{2}{*}{\begin{tabular}{l|} 
df \\
3
\end{tabular}} & \multirow{2}{*}{\begin{tabular}{|r|} 
Mean Square \\
13.537
\end{tabular}} & \multirow{2}{*}{\begin{tabular}{c|}
$\mathrm{F}$ \\
31.188
\end{tabular}} & \multirow{2}{*}{$\begin{array}{l}\text { Sig. } \\
\qquad .000^{\mathrm{b}}\end{array}$} \\
\hline \multirow{3}{*}{1} & Regression & & & & & \\
\hline & Residual & 14.757 & 34 & .434 & & \\
\hline & Total & 55.368 & 37 & & & \\
\hline & ependent Varia & asi.kerja & & & & \\
\hline
\end{tabular}


Pada tabel 7 diatas terlihat bahwa nilai Fhitung adalah 31,188 dan nilai signifikansi 0,000. Diketahui nilai Ftabel dengan tingkat kepercayaan 95\% ( $\alpha: 0,05)$ adalah 2,840. Oleh karena itu nilai Fhitung $>F_{\text {tabel }}(31,188>2,840)$ maka $\mathrm{H}_{\mathrm{O}}$ ditolak dan menerima hipotesis dalam penelitian ini yaitu bahwa pengawasan, lingkungan kerja dan fasilitas kerja secara simultan memiliki pengaruh yang positif dan signifikan terhadap prestasi kerja pegawai Dinas Pangan dan Pertanian Kota Tanjungbalai sebesar 31,188

\subsection{Pengujian Secara Parsial (Uji t)}

Tabel 8. Hasil Uji Parsial Variabel X Terhadap Y

\begin{tabular}{|c|c|c|c|c|c|c|}
\hline \multicolumn{7}{|c|}{ Coefficients $^{\mathbf{a}}$} \\
\hline \multirow{2}{*}{\multicolumn{2}{|c|}{ Model }} & \multicolumn{2}{|c|}{$\begin{array}{l}\text { Unstandardized } \\
\text { Coefficients }\end{array}$} & \multirow{2}{*}{$\begin{array}{l}\text { Standardized } \\
\text { Coefficients } \\
\text { Beta }\end{array}$} & \multirow[t]{2}{*}{$\mathrm{t}$} & \multirow[t]{2}{*}{ Sig. } \\
\hline & & \begin{tabular}{l|l}
$\mathrm{B}$ & \\
\end{tabular} & Std. Error & & & \\
\hline \multirow{4}{*}{1} & (Constant) & 3.790 & 4.454 & & .851 & .401 \\
\hline & pengawasan & .374 & .095 & .407 & 3.937 & .000 \\
\hline & lingkungan.kerja & .257 & .087 & 292 & 2.942 & .006 \\
\hline & fasilitas.kerja & .341 & .097 & .389 & 3.507 & .001 \\
\hline
\end{tabular}

a. Dependent Variable: prestasi.kerja

\subsubsection{Pengaruh Pengawasan Terhadap Prestasi Kerja}

Untuk mengetahui secara parsial pengaruh pengawasan terhadap prestasi kerja pegawai dapat dilihat pada tebel 8 diatas. Berdasarkan tabel tersebut diperoleh nilai thitung sebesar 3,937 dan nilai signifikansi 0,000 . Sedangkan nilai tabel pada tingkat kepercayaan 95\% ( $\alpha: 0,05)$ adalah 2,021. Oleh karena itu nilai thitung $>$ tabel $(3,937$ $>$ 2,021) maka $\mathrm{H}_{\mathrm{O}}$ ditolak dan menerima hipotesis dalam penelitian ini yaitu pengawasan secara parsial berpengaruh positif terhadap prestasi kerja pegawai Dinas Pangan dan Pertanian Kota Tanjungbalai sebesar 3,937.

\subsubsection{Pengaruh Lingkungan Kerja} Terhadap Prestasi Kerja

Untuk mengetahui secara parsial pengaruh lingkungan kerja terhadap prestasi kerja, dapat dilihat pada tebel 8 diatas. Berdasarkan tabel tersebut diperoleh nilai thitung sebesar 2,942 dan nilai signifikansi 0,006 . Sedangkan nilai tabel pada tingkat kepercayaan 95\% ( $\alpha: 0,05)$ adalah 2,021. Oleh karena itu nilai thitung > tabel ( 2,942 > 2,021) maka $\mathrm{H}_{\mathrm{O}}$ ditolak dan menerima hipotesis dalam penelitian ini yaitu lingkungan kerja secara parsial berpengaruh positif terhadap prestasi kerja pegawai Dinas Pangan dan Pertanian Kota Tanjungbalai sebesar 2,942.

\subsubsection{Pengaruh Fasilitas Kerja Terhadap Prestasi Kerja}

Untuk mengetahui secara parsial pengaruh fasilitas kerja terhadap prestasi kerja, dapat dilihat pada tebel 8 diatas. Berdasarkan tabel tersebut diperoleh nilai thitung sebesar 3,507 dan nilai signifikansi 0,001. Sedangkan nilai tabel pada tingkat kepercayaan 95\% ( $\alpha$ : $0,05)$ adalah 2,021. Oleh karena itu nilai thitung > tabel $(3,507>2,021)$ maka $\mathrm{H}_{\mathrm{O}}$ ditolak dan menerima hipotesis dalam penelitian ini yaitu variabel fasilitas kerja secara parsial berpengaruh positif terhadap prestasi kerja pegawai Dinas Pangan dan Pertanian Kota Tanjungbalai sebesar 3,507.

\subsection{Uji Koefisien Determinasi $\left(\mathbf{R}^{2}\right)$}

Uji determinan adalah uji yang dilakukan untuk mengetahui seberapa besar pengaruh variabel independent terhadap variabel dependent. Untuk melihat hasil uji determinan maka dapat diketahui nili $\mathrm{R}$ Square atau koefesien determinasi dan dapat dilihat dibawah ini. 
Tabel 9. Model Summary

\begin{tabular}{|c|c|c|c|c|c|c|}
\hline \multicolumn{7}{|c|}{ Model Summary ${ }^{b}$} \\
\hline \multirow[t]{2}{*}{ Model } & \multirow[t]{2}{*}{$\mathrm{R}$} & \multirow[t]{2}{*}{ R Square } & \multirow{2}{*}{$\begin{array}{l}\text { Adjusted R } \\
\text { Square }\end{array}$} & \multirow{2}{*}{$\begin{array}{l}\text { Std. Error of } \\
\text { the Estimate }\end{array}$} & \multicolumn{2}{|c|}{ Change Statistics } \\
\hline & & & & & $\begin{array}{l}\text { R Square } \\
\text { Change }\end{array}$ & F Change \\
\hline 1 & $.856^{\mathrm{a}}$ & .733 & 710 & .65882 & .733 & 31.188 \\
\hline
\end{tabular}

Nilai R Square pada tabel 5.15. diatas adalah 0,733. Dengan demikian bahwa sebesar $73,30 \%$ variabel prestasi kerja pegawai Dinas Pangan dan Pertanian Kota Tanjungbalai sebesar dapat di jelaskan oleh variabel pengawasan, lingkungan kerja dan fasilitas kerja sedangkan sisanya sebesar $26,70 \%$ di jelaskan oleh variabel lain yang tidak ikut di teliti.

\section{Kesimpulan}

1) Pengawasan secara parsial berpengaruh positif terhadap prestasi kerja pegawai Dinas Pangan dan Pertanian Kota Tanjungbalai sebesar 3,937

2) Lingkungan kerja secara parsial berpengaruh positif terhadap prestasi kerja pegawai Dinas Pangan dan Pertanian Kota Tanjungbalai sebesar 2,942

3) Fasilitas kerja secara parsial berpengaruh positif terhadap prestasi kerja pegawai Dinas Pangan dan Pertanian Kota Tanjungbalai sebesar 3,507

4) Pengawasan, lingkungan kerja dan fasilitas kerja secara simultan memiliki pengaruh yang positif dan signifikan terhadap prestasi kerja pegawai Dinas Pangan dan Pertanian Kota Tanjungbalai sebesar 31,188

5) Diketahui nilai $\mathrm{R}$ Square adalah 0,733 . Dengan demikian bahwa sebesar 73,30\% variabel prestasi kerja pegawai Dinas Pangan dan Pertanian Kota Tanjungbalai sebesar dapat di jelaskan oleh variabel pengawasan, lingkungan kerja dan fasilitas kerja sedangkan sisanya sebesar $26,70 \%$ di jelaskan oleh variabel lain yang tidak ikut di teliti.

\section{DAFTAR PUSTAKA}

Baharudin, Aris dkk. 2013. Pengaruh Pelatihan, Kompensasi Dan Disiplin Kerja Terhadap Prestasi Kerja Karyawan (Studi Pada Kantor PT.PLN (Persero) Area Pelayanan dan Jaringan
Malang), Jurnal Manajemen dan Bisnis, 56-68.

Barthos, Basir. 2015. Manajemen Sumber Daya Manusia. Jakarta: Bumi Aksara.

Brotoharsojo, Hartanto \& Wungu, Jiwo, 2013.

Tingkatkan Kinerja Perusahaan dengan Merit System. Jakarta: PT. Rajagrafindo Persada.

Bernardin, H. John dan Russel. 2012.

Human Resource Management

(Manajemen Sumber Daya Manusia).

Ahli Bahasa Achmad S. Ruky. Jakarta: PT

Gramedia Pustaka.

Chris Rowley, Keith Jackson. 2014.

Manajemen Sumber Daya Manusia:

The Key Concepts. Jakarta: PT. Raja Grafindo Persada.

Danim, Sudarwan. 2014. Kinerja Staf dan Organisasi Perspektif Pendidikan, Pelatihan, Pengembangan dan kewidyaiswaraan Berbasis Kinerja. Bandung: Pustaka Setia

Djojowirono. 2015. Manajemen. Yogyakarta: Teknik Sipil UGM.

Djumati dan Bambang. 2014. Pengaruh kompensasi, fasilitas kerja dan lingkungan Kerja Terhadap Prestasi kerja Pegawai Pada Dinas Perhubungan Komunikasi dan Informatika Kabupaten Kutai Timur. Jurnal.

Ernie, Tisnawati Sule. 2015. Pengantar Manajemen. Depok: Prenadamedia Group.

Fattah, Nanang. 2014. Landasan Manajemen Pendidikan. Bandung: Remaja Rosda karya.

Flippo, Edwin B. 2012. Personel Management (Manajemen Personalia), Edisi. VII Jilid II, Terjemahan Alponso S. Jakarta: Erlangga.

Handoko, T. Hani. 2013. Manajemen Sumber Daya Manusia. Yogyakarta: BPFE. 
Hartanto, R. D. 2015. Pengaruh Komunikasi, Kepemimpinan dan Budaya Organisasi terhadap Kinerja karyawan Pada PDAM Kabupaten Demak. Semarang: Fakultas Ekonomi Universitas Stikubank.

Hasibuan, Malayu S.P. 2015. Organisasi dan Motivasi. Jakarta: Bumi Akasara. 2016. Manajemen Dasar Pengertian dan Masalah. Jakarta: Bumi Akasara.

Husnan, Saud. 2012. Manajemen Personalia. Yogyakarta: BPFE UGM.

Kansil, C.S.T. 2012. Pokok-Pokok hukum kepegawaian Republik Indonesia. Jakarta: Pradnya Paramitha.

Kartono, Kartini, 2012. Pemimpin dan Kepemimpinan: Apakah Pemimpin Abnormal Itu?. Jakarta: RajaGrafindo Persada.

Kopelman, R.E. 2011. Managing Productivity in Organization a Practice People Oriented Prespective. New York: McGraw Hill Book Company.

Kristiansen. 2011. Pengaruh Kemampuan Kerja, Pengawasan dan Fasilitas Kerja Terhadap Prestasi kerja Karyawan Studi Pada Karyawan Operator PT. Indonesia Power Unit Bisnis Pembangkitan. Jurnal.

Lewa dan Subowo. 2011. Pengaruh Kepemimpinan, Lingkungan Kerja Fisik Dan Kompensasi Terhadap Kinerja Karyawan Di PT. Pertamina (Persero) Daerah Operasi Hulu Jawa Bagian Barat, Cirebon. Jurnal Sinergi. Hal $129-140$.

Lupiyoadi, Rambat. 2012. Manajemen Pemasaran Jasa. Edisi 2. Jakarta: Penerbit Salemba Empat.

Mangkunegara. 2010.

Sumber Daya Manusia

Perusahaan. Bandung: Remaja

Rosdakarya. , 2011. Evaluasi Kinerja Sumber Daya Manusia. Bandung: Remaja Rosdakarya.

2012. Perencanaan dan Pengembangan Sumber Daya Manusia. Bandung: Remaja Rosdakarya.

Manullang, Marihot. 2014. Manajemen Sumber Daya Manusia. Yogyakarta: BPFE. 2016. Dasar - Dasar Manajemen. Yogyakarta: BPFE.
Moenir. 2011. Transformasi Pelayanan Umum di Indonesia. Jakarta: PT. Bumi Aksara.

Mulyasa. 2013. Manajemen dan Kepemimpinan Kepala Sekolah. Jakarta: Bumi Aksara.

Nazhifah A. dan Jacky Sumarauw. 2017. Pengaruh Kompensasi, fasilitas kerja dan Beban Kerja Terhadap Prestasi Kerja Pegawai Pada PT. Bank Tabungan Negara (Persero), Tbk Kantor Cabang Manado. Jurnal.

Nawawi, Hadari. 2011. Manajemen Sumber Daya Untuk Bisnis. Yogyakarta: Gadjah Mada University Press.

Newstrom. John W., Davis, Keith. 2017. Perilaku Dalam Organisasi. Edisi Ke tujuh. Alih bahasa, Agus Dharma. Jakarta: Erlangga.

Nitisemito, Alex, S. 2010. Manajemen Personalia. Cetakan Ketiga. Jakarta: Ghalia Indonesia.

Panggabean, S Mutiara. 2014. Manajemen Sumber Daya Manusia. Jakarta: Ghalia Indonesia.

Purwanto. 2012. Psikologi Pendidikan. Bandung: PT Remaja Rosdakarya. Rachman, Taufiq. 2011. Manajemen Sumber Daya Manusia Perusahaan. Bogor: Ghalia Indonesia.

Riduan. 2017. Aplikasi Statistika dan Metode Penelitian Untuk Administrasi dan Manajemen. Bandung: Dewa Ruci.

Riva'i, Veithzal, dan Afrizal. 2012. Kepemimpinan dan Perilaku Organisasi. Jakarta: PT. Raja Grafindo Persada.

Robbins, Stephen P. 2010. Perilaku Organisasi. Jakarta: Salemba Empat. 2017. Manajemen Jilid

1/ Stephen P Robbins dan Mary Coulter diterjemahkan oleh Bob Sabran, Wibi Hardani. -Ed.10, Cet13-. Jakarta: Erlangga.

Safrudin, Alwi. 2012. Manajemen Sumber Daya Manusia. Yogyakarta: BPFE. Sanidhia dan Widiyanti. 2011. Psikologi Dalam Perusahaan. Jakarta: Rhineka Cipta.

Santosa, Purbayu Budi. 2014. Statistika Deskriptif Dalam Bidang Ekonomi

Dan Niaga. Jakarta: Erlangga.

Satriadi. 2015. Pengaruh Kepemimpinan Kepala Sekolah terhadap Kinerja Guru. Jurnal penelitian. Sekolah Tinggi 
Ilmu Ekonomi Pembangunan

Tanjungpinang, Kepulauan Riau.

Sedarmayanti. 2010. Manajemen Sumber

Daya Manusia Strategik. Bogor:

Ghalia Indonesia.

2011. Tata Kerja dan

Produktivitas Kerja. Bogor: Ghalia Indonesia.

Siagian, Sondang P. 2013. Manajemen

Sumber Daya Manusia. Jakarta: CV Haji Masagung.

Situmorang \& Juhir. 2011. Manajemen Sumber Daya Manusia. Bandung: Pustaka Setia.

Soehardi, Sigit. 2013. Perkembangan Pikiran - Pikiran Manajemen dan Pendekatan-Pendekatannya.

Yogyakarta: Armurrita.

Sugiyono. 2013. Metode Penelitian

Bisnis Cetakan kesembilan. Bandung:

Alfabeta.

$\begin{array}{lrr}\text { Penelitian } & 2014 . & \begin{array}{r}\text { Metode } \\ \text { Pendidikan }\end{array} \\ \text { Pendekatan }\end{array}$ Kualitatif, Kuantitatif dan $R$ \& D. Bandung: Alfabeta.

Suharyadi. 2016. Statistika Untuk Ekonomi Dan Keuangan Modern Edisi 2 Buku

2. Jakarta: Salemba Empat.

Sutiko, M. Sobry. 2016. Pimpinan dan Gaya Kepemimpinan. Lombok: Holistica.

Syafiah dan Wima. 2014. Pengaruh Kemampuan, fasilitas kerja dan Motivasi Terhadap Prestasi Kerja Pegawai Kantor Pelayanan Terpadu Studi Pada Kantor Pelayanan Terpadu Lumajang. Jurnal.

Sylia Indra Loana. 2014. Pengaruh Pengawasan, Kompensasi dan Lingkungan Kerja Terahadap Prestasi Kerja Karyawan pada PT. AXA Finnancial Indonesia. Tesis.

Terry, George R. 2011. Prinsip-Prinsip Manajemen, penerjemah J-Smith

D.F.M. Jakarta: PT Bumi Aksara.

Triton, PB. 2016. Manajemen Sumber Daya Manusia: Perspektif Partnership dan Kolektivitas. Yogyakarta: Tugu.

Ukas, Maman. 2014. Manajemen: Konsep, Prinsip dan Aplikasi. Bandung: Agnini.

Umi Kalsum. 2010. Pengaruh faktor -faktor lingkungan kerja Terhadap Prestasi Kerja Karyawan bagian produksi pada PT. Pesona Remaja Malang. Tesis.
Wahjosumidjo. 2011. Kepemimpinan dan Motivasi. Jakarta: Ghalia Indonesia. Wexley \& Yukl, 2013. Perilaku Organisasi dan Psikologi Personalia. Jakarta: Rineka Cipta.

Wursanto. 2013. Dasar-Dasar Ilmu Organisasi. Yogyakarta : Andi.

Yolder, Dale. 2014. Manajemen Sumber Daya Manusia. Bandung: Erlangga. 